\title{
In Search of Employee Perspective: Understanding How Lithuanian Companies Use Employees Representatives in the Adoption of Company's Decisions
}

\author{
Remigijus Civinskas ${ }^{1,+}$ and Jaroslav Dvorak ${ }^{2, *,+}$ (D) \\ 1 Department of Public Administration, Faculty of Political Sciences and Diplomacy, Vytautas Magnus \\ University, 23-604 V. Putvinskio str., 44243 Kaunas, Lithuania; r.civinskas@pmdf.vdu.lt \\ 2 Department of Public Administration and Political Sciences, Faculty of Social Sciences and Humanities, \\ Klaipeda University, H. Manto 84, 92294 Klaipeda, Lithuania \\ * Correspondence: jaroslav.dvorak@ku.lt \\ + These authors contributed equally to this work.
}

Received: 14 September 2019; Accepted: 2 October 2019; Published: 4 October 2019

\begin{abstract}
The article analyzes the factors of the use of employees' representatives in the adoption of a company's decision in Lithuanian companies. The methodology of current research is based upon the data collected through a quantitative expert-based survey and qualitative interviews with representatives of trade unions. The survey method has been used in order to obtain the data from the experts involved in the field of industrial relations in Lithuania. The interviews with representatives of trade unions gives a possibility to look at how people perceive the employee participation methods proposed by the employers, what benefits they see in their use and what policy does their organization or collective apply towards these means (trade unions etc.). According to the research findings, the employee's participation is called a social dialogue at the company level. The results of the current research in favor evaluate the constructive cooperation between the employee representatives and employers (when this does not encompass important areas of industrial relations (i.e., collective agreements, negotiations regarding wages, employment conditions etc.)).
\end{abstract}

Keywords: employees' representatives; company's decision; industrial relations; participation; trade unions

\section{Introduction}

Many, often very complex, factors may determine the points of view of the employee representatives and decisions regarding the forms of employee participation proposed by the employers. Ideological and value views and interests determine the point of view of the employee and employers' representatives towards this phenomenon. Often, they are cardinally contradictory and sometimes they look for constructive points of contact and agreements. For Lithuanian trade unions, the indirect participation of the employee (the mechanisms, by which the employees may be included in the adoption of company's management decisions, save for information, consultation and negotiation processes) is slightly familiar, but not always understandable. This is one of the reasons why the representatives of the employees react differently to the indirect forms of involvement (financial participation, teamwork, quality circles, schemes of innovative proposals etc.) proposed by the employers. Sometimes, they take-up the pluralistic standpoint,- - they think about common benefits for the employees, as well as for the employers. Often conversely, they react towards all of the proposals of the employers regarding the involvement of employees by using managerial and other means 
very critically, thinking that the foundation of effective operation may only be resistance against the employers or acting based on agreements and procedures formalized by the laws (the so-called forms of direct participation).

The trade unions pay relatively small attention to the phenomenon being analyzed and the employers relatively seldom apply the means of including the employees into the decision making. On the other hand, the international corporations apply the schemes of employee involvement (by unifying the management of corporations, they transfer the philosophies of quality management, socially responsible business of the "mother" company, as well as the schemes of employee involvement). This provides clear message to all stakeholders that company is an instrument for organization of the company. Gradually, the national company's tryout some business philosophies and involvement schemes of employees. Thus, the understanding of these ideas and practical management means maintain a certain relevance. Furthermore, the European Commission and other EU institutions broaden, develop and encourage the notions of the EU's industrial democracy. Moreover, EU institutions support some forms of indirect participation (especially related with collective participation, when the majority of employees are represented).

The data, which disclose low-level employee participation and representation, substantiate the relevance of the research. For example, in the EU employee representation index (comprised on the percentage scale of 27.78-100; EU member states average is 63.69), Lithuania is in the bottom of the list (27th place out of 28) (Eurofound 2018).

The researchers and experts have broadly enough reviewed the problems of low employee representation in Lithuania (company and sector level). Based on the analysis, they have differentiated a couple of reasons: ineffective representation (Blažienè and Gruževskis 2017), economic crisis (2009-2013) (Dvorak et al. 2018), unsustainable companies (Šimanskienè and Župerkienè 2013) and a negative impact of soviet heritage and post-soviet tradition (Lulle 2013; Sippola 2017). It is also relevant because there has been little research into the points of view of the trade unions towards the collective indirect participation forms proposed by the employers in Western countries and Lithuania as well. Only one study and a couple of scientific articles have analyzed the points of view of the representatives of trade unions towards the social responsibility of companies and the financial participation of employees (Pučetaite et al. 2014; Shpak et al. 2018).

The object of the current research-analyze the points of view of the employee representatives and experts working in the field of employment relations towards the indirect participation forms proposed by the employers and applied on the company level. The main aim of this research is to examine how Lithuanian companies use employees representatives in the adoption of company's decisions. The following question guide the research: How and to what extent does the use employee representatives in Lithuanian companies influence indirect participation of employees?

Limitations of the research. The current research consolidated and integrated the data in the initial explanatory framework, due to the lack of such studies in Lithuania. Novelty of the research can be ascribed that the research gives an opportunity to form the theoretical model that can be further justify in the synthetic theory.

\section{The Participation of Employee Representatives in the Adoption of Company's Decisions: Notions and Access to Researches}

In public, political and academic discourses, the employee participation is understood as multiple phenomenon. Scientists associate this topic with different disciplines and research directions. Ideological and value views and interests determine the point of view of the employee and employers representatives towards this phenomenon. Often, they are cardinally contradictory and sometimes they look for constructive points of contact and agreements. For example, traditional debates (also called direct, formal participation, the modus operandi of which is the operation of trade unions in the companies and the negotiation process, the signing and control of collective agreement and other agreements with the employers), which are noticeable in the academic field of research, may 
be coordinated with the forms of indirect participation (the metaphor of "velvet gloves" is accurate), which are initiated by the employers.

By looking into the academic interest field, it can be noticed, that the researchers of labor law, industrial relations, organizational psychology, human resources most often take interest in the participation of employee representatives in the adoption of company's decisions (Mowbray et al. 2015; Kaufman 2015). The scientists, by applying the notions and theories (unitary, conflict, systems) acceptable to them, review this phenomenon from different access points.

Upon solving the issue of the conceptual multidimensional (industrial democracy, voice, involvement, social dialogue, employee participation) of the phenomenon, the scientists often apply metaphors for the explanation of it. This way, a clarity is introduced for those, who are interested in this area. Traditionally, the participation of employees is understood as a part of industrial democracy (Sidney and Beatrice Webbs have used this "umbrella" like and heterogenic content notion as far back as 1897) ${ }^{1}$. Often, the participation of employees is defined as "the collective voice of employees" ${ }^{2}$, "the involvement of employees" and "two-sided social dialogue". In addition, narrower notions are used-"information sharing", "capitalization of employees" (financial participation of employees), "high level involvement in the management of human resources" etc. (Markey and Townsend 2013; Kozłowski 2014; Machado 2016; Civinskas and Dvorak 2017). The discussed forms of employee participation determine the use of these notions. It is noticeable, that professionals and politicians accepted the majority of these notions and are using them broadly. It means that industrial democracy has two clear point: Voice and involvement. Voice effect can be measured by using financial criteria (achieved salary level), however it is difficult to measure effect of involvement in company decision-making. An involvement effect may focus on either lower awareness/non- participation or higher awareness/participation imperatives (Laurenas 2017).

Very complex notions having multiple meanings and associated with the topic of employee participation raise many miscommunication problems among the academics, political actors and industrial relations participants (Heery 2015). Many reasons have determined this, but the most important are value and ideological provisions.

By following the criterion of employees and employers interests, the researchers distinguish three competing interpretations regarding the participation of employees: (1) Unitarian (it is thought, that the interests of employees and employers are fully compatible and there may be a cooperation in industrial relations); (2) pluralistic (a precondition is followed, that there is an unavoidable conflict between the employees and employers encompassing the most important areas of industrial relations: negotiations regarding wages, work conditions etc. The pluralists think that while searching for mutual benefit, both sides can look for compromises and common solutions; however, they cannot lean solely on the initiative of employers. The followers of such standpoint adheres to the notion, that the best form of employee participation in industrial relations is the operation of trade unions in the companies and negotiations on the basis of collective agreement); (3) critical (it is interpreted that the interests of employees and employers differ radically, due to the fact, that industrial relations in essence are exploitable and inhumane. Due to these reasons, the employees must constantly resist) (Heery 2015; Johnstone and Wilkinson 2016).

It is important to note that these notions are not only narrowly related to the field of scientific research. The employers, trade unions and public politics actors follow the pluralistic, Unitarian and, less frequently, critical notions. In the understanding of industrial relations, these perspectives slowly

1 In a broader sense, the industrial democracy is an area of agreements, which encompasses the involvement of employees into the adoption of decisions when sharing responsibilities and authorities at the workplaces (Webb, Sidney, and Beatrice Webb. Industrial democracy. Vol. 1. Longmans, green, and Company, 1897).

2 Some metaphors have essential shortfalls. For example, the notion of "the voice of the employee" envisages that the employees may only "express" their position. Whereas, the term of "participation" holds more power, because it can also encompass the effect on the adoption of decisions. 
draw near (especially this could be stated regarding the search of common points among the followers of pluralistic and Unitarian tradition) (Johnstone and Wilkinson 2016). The EU institutions, politicians and responsible officers are searching for ideological contact points, which are determined by mutual contributions and benefit, among the employees and employers at the companies' level as well.

The EU notion of industrial democracy's relations follows the fundamental ideas regarding the importance of collective negotiations and consultation (in USA and other countries, the state or market is often accentuated) (Marginson 2017). Nevertheless, the EU's industrial democracy notion is complex enough. Furthermore, the EU's industrial democracy notion has changed over the decades. However, it continues to engage in wider practice that raising this policy problem to the entire policy cycle.

A couple of decades ago, the industrial democracy of EU was based on normative ideas and political arguments, which were tied with the creation and application of "democratic social economics" concept (European Commission 2002). The policy shapers "wedged" the newly defined ideas into the Lisbon Strategy. The actors of the political linked the EU's "democratic social economics" with the development of industrial democracy and strengthening of competition. In the recent years, the development of industrial democracy is also associated with social cohesion (this was enshrined in the document of EC “The European Pillar of Social Rights") (European Commission 2017).

The ideas of EU's industrial democracy at the companies' level were enshrined in the regulation of the EU. The general information and consultation model of the employees was defined in the Directive 2002/14/EC of the European Parliament and of the Council (European Parliament and Council 2002). In this way, the informing and consulting of the employees became the basis of the EU's industrial relations scheme (Marginson 2017). The EU's industrial democracy relation ideas and principles, norms enshrined in the EU law were and are applied in the national law of member states. It is true that not only the EU agreements influenced the regulation of industrial relations in the member states, but also the structural reforms being implemented (most countries reacted to crises by carrying-out neoliberal reforms) (Hyman 2018).

Finally, we can move to the general definition of the employee's participation in the activities of the company. European Foundation for the Improvement of Living and Working Conditions (tripartite EU agency of social, employment and work related policies, Eurofound) defines the participation of employees as: "Mechanisms, based on which the employees may be included in to the managerial decision making of the company, save for employee informing, consulting and negotiating means" (Eurofound 2016).

The researches, who have conducted the meta-analysis of concept and theoretical standpoints, similarly defined the phenomenon being discussed. The essential difference is related with slightly different views towards the informing and consulting of employees as the forms of employee participation. To put it more precisely, the theoreticians and professionals define the employee participation broader than it is defined in the documents analyzing the EU policies (the 2015 Eurofound research report, which is meant for researching the employee participation, substantiates this (Eurofound 2015).

\section{The Forms of Employee Participation in the Decision Adoption of the Company: Direct and Indirect Participation}

The participation of employees in the company's decision adoption may be direct or indirect (also called formal vs informal). Direct employee participation is understood as "the participation of representatives" (the employee representatives, who were elected or assigned by the trade union or employees' council, in the boards and others) (Wilkinson et al. 2013). This form is sometimes called a social dialogue at the level of companies (Mailand and Due 2004). Via certain forms of representation (granting of authority upon election or assignation), informing, consulting, inclusion into the collegial management bodies and otherwise, the employees are included into the adoption of decisions. It is important to highlight, that the labor law of the EU and member states institutionalizes the employee participation in part and regulates it clearly enough. The collective negotiations, the right to take up collective actions and their practical realization are very important in this form of participation. 
Indirect participation encompasses individual and collective forms of employee participation in the adoption of decisions in the companies. Wilkinson and Dundon (2010) argue, that: "in a broader sense, the direct participation of employees may be understood as the consultations of employee delegates with the employers, and in a narrower sense, it can be linked with formal consultation structures (the employers can determine them)". In accordance to this conception, the employers in the companies initiate and motivate the inclusion of the employees by consulting or transferring the responsibilities in the adoption of managerial decisions (also called "consultation participation"). Such forms of consultation are applied to individual employees, as well as their groups. However, it is important to note, that the employers consult with the employees, but they reserve the right to adopt the final decision without having to move to negotiations.

Many researchers note that the forms of direct and indirect employee participation often interlace and supplement one another (Marchington and Wilkinson 2005; Wilkinson and Dundon 2010). Thus, it is difficult for the scientists to determine the importance of one or the other form for the adoption of decisions in a specific company. However, it is simply a question on how to choose a correct methodology. The essential matter is to evaluate the importance of these forms. Towards the indirect employee participation, the professionals and academics take up two-fold stances: (1) One group is of the opinion that this form only supplements direct participation, which is an essential part. Furthermore, they accentuate that these two participation forms are associated with different organizational processes (indirect participation concerns the policy regarding the technologies of the company and investments, while direct participation concerns wage, employment conditions etc.); (2) the other group accentuates that there exist competing forms of participation and they often encompass one other. It is important to note that the human resources researchers more often uphold the second standpoint, while the industrial relations sociologists—-the first one (Marchington and Wilkinson 2005; Kim et al. 2010; Wilkinson and Dundon 2010). Thus, the inclusion of the members of employee representatives (trade unions, work councils) are a secondary factor for them (it is understood as a variable of the organizational environment, to which regard must be had, however, it is not critical) (Della Torre 2018). On the other hand, the scientists understand the relationships, which are based on the communication between the management and trade unions, as a certain guarantee for success.

In this article, an exceptional attention is paid to the forms or mechanisms of indirect employee participation in the adoption of decisions in the companies and to the point of view of trade unions in regard to them, (the aspect of company's activity results is distinguished). In other words, the points of view of trade unions (they are the actors in the mechanisms of direct participation and have their own "voice" in the company) towards indirect forms of participation are discussed.

A couple of matters determined such a standpoint of the research. First, this was determined by the goal and tasks of the ordered research. Secondly, it is very important that there are only a few researches done on this topic in the EU and Lithuania. Firstly, it can be noted, that there is no clear standing concept associated with the indirect means of collective inclusion of employees in the company's management. A couple of reasons determined this. First, some human resources researches think that the object of the research is unimportant when analyzing the indirect forms of employee participation. Whereas the sociologists, who analyze industrial relations, mostly researches the interactions of direct and indirect participation. Secondly, for a couple of decades, the importance of trade unions and abundance of memberships in them have been dwindling in the West (Crouch 2017; OECD 2018). Therefore, these researches are as if irrelevant. However, in the industrial relations of the post-industrial cultures, due to complex reasons, the employers more often initiate the indirect participation (at least on an individual level) as a means to control human resources and a method to decrease the impact of trade unions.

Individual empirical researches disclose that collective employee participation in indirect forms remains relevant enough in separate countries of the EU (Barry and Wilkinson 2016; Della Torre 2018). The Eurofound (2015) research regarding the participation of employees in the adoption of company's decisions uncovered, that indirect participation of employees in the member states of the European 
Union is relatively undeveloped. According to the research, only a part of companies (13\%) shares information about strategic activities with the employees and the quality of information is sufficiently poor (Eurofound 2015). In addition, this study determined that there exists no direct dependability between information sharing and work councils or organizations of trade unions acting in the companies. On the other hand, the analytics submitted their conclusions, that in the countries, which do not distinguish themselves with the tradition of trade unions, more often the employers initiate the schemes of indirect participation. Another common pattern is that large companies, in which trade unions operate, apply the schemes of indirect employee participation more often than small and medium sized companies do. A couple of researches explain this with an argument that in Europe, as per tradition, the direct participation in a form of negotiations through trade unions and partially work councils remains important (Brewster et al. 2007).

\section{Collective Indirect Forms of Employee Participation}

The employers have created and developed a whole range of collective employee participation in the adoption of decisions in the companies' forms (also called structures). As it was mentioned, they are often differentiated from the direct participation forms, - trade unions operating in the companies and influential and strong councils ${ }^{3}$. It is also important, that the employees be included into the decision of the company collectively (Gollan 2010).

The employers in Anglo-Saxon countries created and developed forms of indirect participation. The employers created them as additional forms for informing, consulting the employees or other participation in the adoption of decisions. More precisely, a part of companies kept the structures of working with trade unions (negotiations regarding employment conditions, wages etc., as well as the conclusion of the collective agreement), but other forms of employee inclusion started to operate under them. Another reason, which influenced the application of indirect employee participation forms, was the decrease in members of trade unions. Thus, part of the employers wanting to communicate and hear the collective created specific communication and participation in the adoption of the decisions channels.

As it was mentioned earlier, the employers create the forms of indirect employee participation in order through information and consultation to achieve a larger activity of productivity. The supporters of this model of participation submit their arguments: (1) It creates a harmonious human resources management (or employment relations) environment in comparison to the interaction with trade unions (Gollan 2010; Gollan and Xu 2015); (2) it is an effective means of reconciliation of interests, which ensures certain authority and control over decisions to the employees; (3) it is the representation of employees; (4) autonomy and discretion over decisions is granted (Markey and Knudsen 2014).

The scientists, while examining the forms of indirect employee participation in workplaces, distinguish two types of participation: Organizational and financial (encompasses the forms of profit sharing and financial participation) (see the image). From couple of main to couple of dozen forms of participation are attributed to the organizational participation. Most often, these well-established forms are differentiated in the company: special work teams (autonomous problem solving groups, problem solving teams, quality circles, joint consultation committees, complaint acceptance systems) and schemes of innovative proposals (they are more often oriented towards the technological-organizational innovations) (see the scheme). Often, these information and consultation forms are included into the strategies of the employers and their operation is formalized by defining them in internal documents.

Other non-institutionalized (also called informal) forms, which are associated with discussions between employers and employees, open door policy, enablement of direct managers etc., supplement

3 Here, influential work councils are understood as those, who are acting in accordance to the lawful and legal basis and can influence the decisions adopted by the representatives of the employers. For example, they can elect or assign their own representatives into the boards. 
them (Mowbray et al. 2015). These forms encompass direct interactions of the employees and employers. These forms grant a certain behavioral discretion to employees and they are heard. By using this method, the employers tend to hear the complaints of the employees (Detert and Treviño 2010). On the other hand, as numerous empiric researches show, the employers, while thinking about greater benefit, often connect and apply different forms of employee participation (Marchington and Suter 2013). For example, the information expressed at the restaurant during the company's party, may not reach all of the employees, thus, the employers are interested to use more formalized methods (inform via meetings, use electronic systems etc.) (see Figure 1).

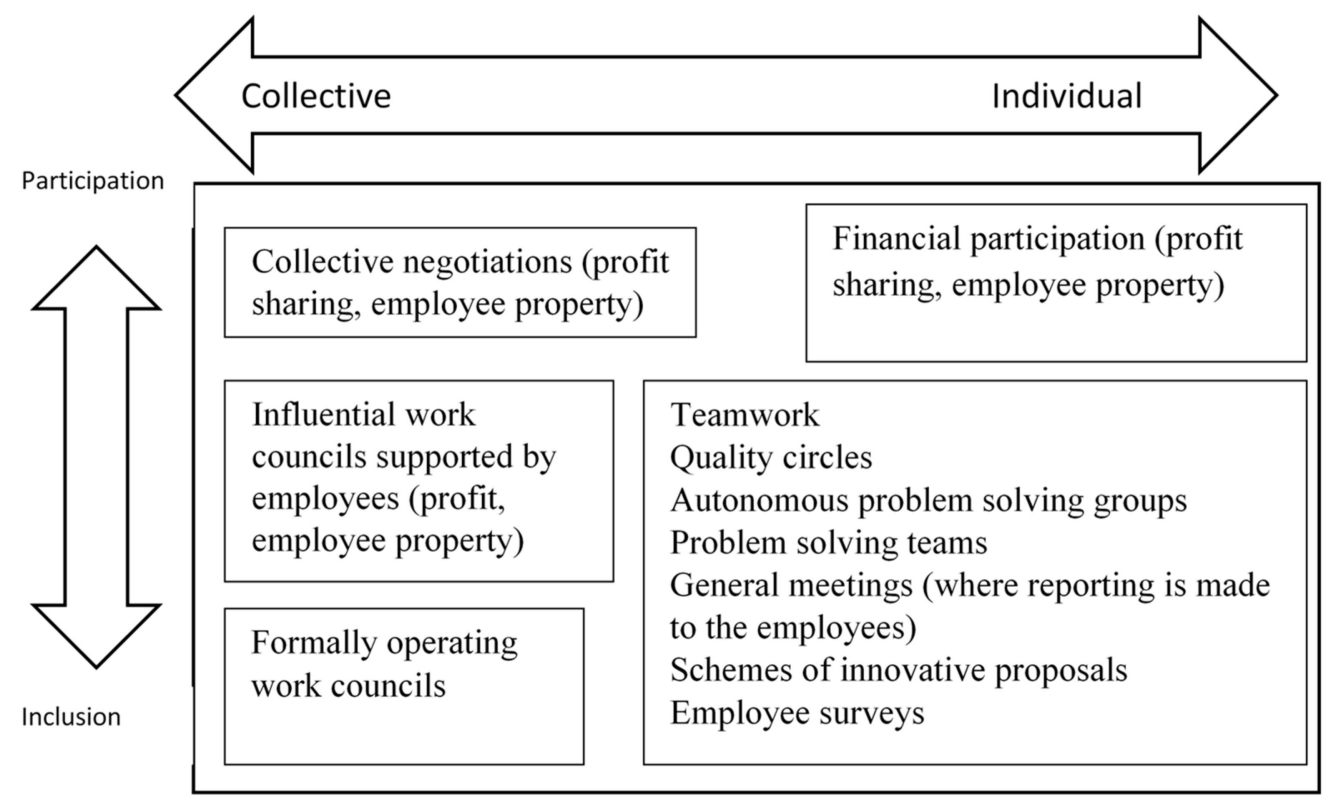

Figure 1. Forms of Employee Participation. Compiled by author by following Brewster et al. (2007) and Mowbray et al. (2015).

In order to determine the influence of participation on the decisions of the company, the scientists Paul Blyton and Peter Turnbull differentiated these levels: "non-inclusion", "informing", "general consulting" and "employee control" (Blyton and Turnbull 1998). By applying these categories, the level of indirect employee inclusion into the adoption of the decision may be understood more thoroughly. On the other hand, this does not encompass a possible business manipulation by simulating the inclusion of employees. Here, Pateman (1970) notion of "pseudo" participation is significant. Based on it, one can differentiate the phenomenon of imitational type of participation.

\section{The Methods and Procedures}

The qualitative research method via the interview (group and individual interviews were conducted, see Table 1) was applied when analyzing the opinions of trade union representatives and experts working in the field of employment relations. A non-representational survey supplemented the qualitative research. 
Table 1. During the research, individual interviews were conducted.

\begin{tabular}{|c|c|c|}
\hline No. & Participant & Code \\
\hline \multicolumn{3}{|c|}{ Individual interviews } \\
\hline 1 & Chairperson of national trade union & NAC1 \\
\hline 2 & Chairperson of national trade union & NAC2 \\
\hline 3 & Chairperson of national trade union & NAC3 \\
\hline 4 & Deputy of the chairperson of national trade union & NAC4 \\
\hline 5 & Deputy of the chairperson of national trade union & NAC5 \\
\hline 6 & General secretary of national trade union & NAC6 \\
\hline 7 & Management member of national trade union & NAC7 \\
\hline 8 & Head of branch trade union (transport sector) & ŠAK1 \\
\hline 9 & Head of branch trade union (food industry) & ŠAK2 \\
\hline 10 & Head of branch trade union (service sector) & ŠAK3 \\
\hline 11 & $\begin{array}{l}\text { Head of the company's trade union (food industry, the company belongs to an } \\
\text { international corporation) }\end{array}$ & IM1 \\
\hline 12 & Head of the company's trade union (transport sector's company) & IM2 \\
\hline 13 & $\begin{array}{l}\text { Member of work council (food industry, the company belongs to an } \\
\text { international corporation) }\end{array}$ & DT1 \\
\hline 14 & Member of work council (food industry sector's company) & DT2 \\
\hline 15 & Expert, the manager of the project of social responsibility of the companies & EK1 \\
\hline 16 & Expert, the head of Lithuanian Responsible Business Association & EK2 \\
\hline \multicolumn{3}{|c|}{ Participants of focus group } \\
\hline 11 & Head of national trade union & \\
\hline 12 & Management member of branch trade union & \\
\hline 13 & Member of branch trade union (jurist) & \\
\hline 14 & Head of company's trade union & \\
\hline 15 & Member of company's trade union & \\
\hline 16 & NGO expert, trade unions' training, activity development area & \\
\hline 17 & NGO expert, trade unions' training, trainings, activity development area & \\
\hline 18 & NGO expert, sustainable development specialist & \\
\hline 19 & NGO expert & \\
\hline
\end{tabular}

Qualitative Research. In total, 15 individual anonymous (and one focus group) interviews were conducted. Four groups of informants may be distinguished (the heads of national trade unions and council members, the heads of branch trade unions, the chairpersons of trade unions of the companies and the experts working the field of employment relations). Most interviews were conducted with the representatives of national and branch trade unions ${ }^{4}$. The duration of individual interviews is from $20 \mathrm{~min}$. and up to an hour. The interviews were conducted in the second half of 2018. Finally, based on the accumulated qualitative data, the survey questionnaire was prepared and a survey conducted.

Deep interviews are beneficial, because they allow finding out the perspectives of the individuals. This is an effective method of qualitative research, in order to force the respondents to disclose thoroughly their point of views and experience associated with the indirect participation of the employee. This method provides a possibility to look at how people understand the employee participation methods proposed by the employers, what benefits they see in their use and what policy does their organization or collective apply towards these means (trade unions etc.). We can achieve this by paying attention to the simple stories of participants on what they experienced and what they believe in and by actively asking questions.

4 These trade unions participated in the research: Lithuanian Trade Union "Solidarumas", Lithuanian Confederation of Trade Unions, Lithuanian Trade Union of Carriers, Lithuanian Trade Union Alliance, Lithuanian Trade Union of Food Producers, Lithuanian Trade Union of Service Field Workers, Lithuanian Industry Trade Union's Confederation, Lithuanian Energetics Sector Workers Trade Union's Federation and Lithuanian Work Federation. 
The Limitations of Qualitative Research. The informants not always can precisely disclose their opinions on employee participation in the adoption of decisions in the companies, because they often mistake this form with direct participation. Thus, upon correcting the questions, the examples of participation forms presented, the formulations of questions corrected etc. Not all of the informants had direct experiences related with the involvement of employees in the adoption of decision at the company level. The information, which was received during trainings and discussions in trade unions, shaped their notions. A couple of informants accentuated a beforehand goodwill towards the discussed initiatives of the employers; this did not allow to openly lie down one's opinion. During the qualitative research, a couple of harder controlled situations emerged. Due to this reason, a marginal material of the interview could not be transcribed. Thus, these factors will be evaluated as limiting.

The survey of the representatives of trade unions, members of work councils and experts was conducted in order to provide explanatory framework of the current situation in the field of employees' representation in company decision-making. The empirical research explains; consolidate the theoretical and practical knowledge on employees' representation in adoption company decisions in Lithuania. The conducted survey was not representative but was implemented according scientifically prescribed procedures. The representatives of trade unions, members of work councils and experts were included in accordance to the pre-determined criterions. There are no comprehensive records or listing of industrial relations practitioners in Lithuania. The most important criterion of respondent selection is the representation of employees in the companies (companies or branches), the founders of which are private persons. Other criterions for the selection of informants were used as well: (1) Representation for the national trade union (heads and council members); (2) representation for branch trade union (heads and council members); (3) the chairpersons of trade unions operating in the companies or work councils, who have encountered the applied practices of indirect involvement of employees in the companies (socially responsible middle and big companies having trade unions and other companies were chosen); (4) experts (academic, couple of state institutions and NGO experts working in the areas of industrial relations, labor law and consultations regarding the activity of trade unions).

The questionnaire of the survey consisted of 13 questions; however, some questions were composite, thus, in total, 42 questions were presented for the respondents. The questions may be differentiated in to three topic blocks: Demographic, points of view towards the cooperation with business, participation of employees in the adoption of decisions of the companies, the knowing about the indirect employee participation models proposed by the employers and the needs to develop the knowledge, as well as, the position of trade unions on the direct participation of employees.

The survey was conducted at the end of 2018. The respondents were asked to fill-out the form electronically on the Internet. However, part of the respondents was contacted by phone; they were not questioned, only reminded about the form and those respondents, who did not fill it out, were asked to fill it. The survey sample was 92 experts (32 chairpersons of trade unions acting at the companies' level, 20 chairpersons or their deputies of branch trade unions, 10 chairpersons of national trade unions or representatives of work councils, 10 chairpersons of work councils, 20 experts representing the academic field and NGO). 42 respondents (46\%) participated in the survey and answered the questions submitted in the form.

The distribution of respondents according to their status is submitted in the table (see Table 2). As it can be seen, the majority of clients represented a trade union (were the chairpersons of it) or were experts acting in the area of industrial relations.

On average, the respondents have been acting 16 years in the area of industrial relations (2 respondents did not indicate their work period).

In this research, the data from the experts' survey are used as supplementing and correcting, introducing a quantitative measurement data, however, they are not primary. When analyzing survey data, the survey is mostly based on the descriptive statistics. When analyzing the viewpoints of the employee representatives towards the indirect participation of employees in the adoption of company's 
decisions, the data from the interviews are used, however, the analysis is corrected and in certain cases, the survey data help to concretize it.

In the further part, it is important to discuss the questions of quantitative research associated with opinions regarding the application of indirect participation forms of the employees and their impact on the results of the activity of companies.

Table 2. The Distribution of Respondents According to Status.

\begin{tabular}{ccc}
\hline Status of Respondents & Number of Respondents & Percentage of Respondents \\
\hline Trade union acting at a company's level & 16 & 38.1 \\
National trade union & 3 & 7.1 \\
Work council & 4 & 9.5 \\
Branch trade union & 6 & 14.3 \\
NGO acting in the area of industrial relations & 1 & 2.4 \\
Expert in the area of industrial relations & 12 & 28.6 \\
$\mathbf{N}=$ & 42 & 100 \\
\hline
\end{tabular}

\section{The Points of View of Employee Representatives towards the Employee Participation in the Adoption of Companies' Decisions}

\subsection{The Marginalization, Avoidance or Effective Supplementation of Employee Agencies}

The qualitative research has uncovered that the employee representatives differently understand the indirect participation of employees. More precisely, the informants by answering the questions described the phenomenon with different notions, metaphors and comparisons. They also differently defined their subject matter (forms were mentioned) and contextualized it. The majority of trade union representatives have indicated it as social dialogue or dialogue in the companies (interviews with NAC1, NAC3; ŠAK1; ŠAK2; NAC6; IM2). A part of other respondents identified the schemes of employee inclusion and informing proposed by the employers with work councils and their establishment or with socially responsible companies (NAC4; ŠAK4). Other respondents did not differentiate direct and indirect employee participation in the adoption of companies' decisions. Only a part of respondents by answering the question regarding the phenomenon being discussed moved on to its separate forms (interviews with NAC2; NAC6).

As it was already mentioned in the conceptual discussion, the heterogeneity and abundance of employee inclusion forms determine the understanding of this phenomenon. Discussion in focus group disclosed this. The informants by expressing their opinions attributed all of this to certain forms of indirect employee participation (interview in a focus group).

However, it is important to have regard to the factors, which have determined these outlooks. As the interview material discloses, a couple of factors influenced the points of view towards financial participation of employees. First, practical experiences of issues and solving of them and specific cases determined the understanding of employee representatives. During the interview, they shared these experiences. The peculiarities of vocational activity influenced this. Secondly, the majority of respondents by trying to answer the questions thought about the changes introduced by the recently started to operate Labor Code, which were associated with the amendments of work council regulations. In addition, they mentioned the failed proposals to introduce the designation of employee representatives to the boards of companies. Thus, the importance of the reform (in their opinion, unfavorable to the employee representatives) and the practical outcomes of it acted as a factor determining opinions. Together this uncovered the legalistic point of view. Thirdly, the points of view of informants and members of trade unions were determined by information received from consultants and partners in international conferences, trainings or by other means. 
A couple of things can be noted when having regard to the normative notions determining the points of view of employee representatives. Firstly, it can be seen that the majority of respondents adhere to the pluralistic provisions ${ }^{5}$. A couple of reflexions disclose this:

Talking and cooperation is needed. As I understand, the employers fear the trade unions, while the trade unions see the employer as a potential villain. However, of course, decisions exist. Talking is needed. There are many examples and variants. Most of them are bad, but there are good examples as well. I have them. For example, there is a logistics company "Transtira" [company case was offered]. There, the trade union works with the employer based on the principle of mediation. All of the issues are forwarded to the trade union and it refines them to real ones, not emotional ones. Later on, there are tries to solve them with the manager. (interview with NAC4)

If the collective agreement exists, then its result is financial participation, allocation of profits and shares. If everything would go through the collective agreement, everything would be splendid. However, if they there ... they share as profit anything. Never will a capitalist employer share their profits, if the said employer will not be forced to do this. The employer is big altruist. Here, exceptional cases are possible. Maybe, I'm not saying. Maybe one or couple of employers are different. (interview with NAC5)

They look to a trade union with white eyes [talking about the points of view of a part of employers towards cooperation]. They do not understand, pre-conditions that the trade unions is a conflict is valid for them. Maybe, this is coming from TV, media, maybe from a tradition. They do not understand what a dialogue is. (interview with ŠAK2)

By reviewing these interviews, it can be noticed that the informants understand the mutual benefit of compromises and cooperation. However, in their opinion, it cannot rest solely on the initiative of the employers. A pre-condition is significant for informants-negotiations and written agreements (first of all, collective agreement), which include the trade union as well. A couple of informants reflected relevant issues this way:

Rarely there is information about financial success. There are few employers, who understand that this is teamwork; it won't be another way. There are few practices of this kind. They do exist, but they are few. Well ... As I've said, negotiations regarding wage, size of it ... it is the most complex question. Even though, now, the issue of wage is supposed to be a part of the collective agreement. However, this is very hard to achieve. For example, today, we had two negotiations and they all went really difficult. Believe me. These are negotiations with international companies, and when negotiations are needed to be had with local companies... Believe me, negotiations are foreign language to them. An international company has its own standards, code of ethics and the collective agreements must be signed in accordance to those documents. [ ... I Yeah, yeah, they must act more respectably and less aggressively. (interview with ŠAK1)

Where there is foreign capital, they bring it with them. They do not want to lose their positions. Their parent companies with their own policy exist. These companies look at it a bit differently. I remember being at "Elemenhorster". The manager says that we give the employees this and this. Nevertheless, this was the chairperson's issue. This I can tell. There was a stubbornness of the trade union's chairperson; he simply said how it's going to be and it was all over. Another matter is in the furniture sector. There talking and giving exist. There good conditions and nourishment, work safety

5 During the interview, it was failed to record a pure critical or Unitarian position of trade union representatives. Only one informant representing the work council expressed an unitarian point of view. In his opinion: "The Employers and employee representatives can always find an agreement. I can say this about my job. If need be, we go to our manager to talk without looking for very sharp angles but expressing our opinions" (interview with DT1). 
and a part of teamwork exist. Nevertheless, here everything comes from the West. Those companies implement their own culture. For our people, as I've mentioned ... Those with "full stomach" are good [talking about Lithuanian capital companies, which are entrenched in the market and are financially stable]. Those, who do not need to catch-on, those, who have branches in foreign countries. Those look at the issue more simply and you understand that then you can talk about the so-called social aspect. You cannot talk with those small ones, who work during weekends and pay wages under the table. (interview with ŠAK2)

In these interview fragments, the informants accentuate not only that the Western corporations transfer the values (through the application of ethical codes of conduct), organizational cultures and models (through the strategies of cooperation with trade unions) of cooperation with trade unions. Such "export" of values at least in part changes the points of view and guidelines of the managers of the companies. Thus, in this way, the foundation for cooperation and in part for trust is created. The employee representatives have noticed that they can factually work in the employment relations area (agree, sign collective agreements) only with Western capital companies.

The second interview fragment discloses, that adapting in Lithuania towards certain organizational cultures, forms of employee and employer cooperation sometimes the chairpersons of trade unions react inflexibly. They take up very strict and unambiguous positions towards the proposals of employers. From the context of the answer, it becomes clear that the trade unions did not want to retreat from the highly raised conditions in regard to the employer.

During the interview, the informants reflected the reasons for mistrust (this was not asked specifically, but was derived from the context of discussions) and attributed them with: (1) Soviet style of managers and management tradition, as well as point of view towards the employee (interviews with NAC3, NAC1, NAC6, DT1, DT2, IM1, focus group); (2) natural logic of employment relations, which determines a certain degree of conflict (interviews with NAC7, NAC2, NAC4); and (3) deeper cultural reasons (negative attitude of the society towards trade unions, and a too little degree of the modernization of society etc.) (interviews with ŠAK1, NAC4).

By the experts and employee representatives survey it was intended to find out what is the point of view of respondents towards the cooperation proposed by the employers when creating constructive dialogue with employee representatives (e.g., trade unions) when this does not encompass important traditional areas of employment relations (i.e., collective agreements, negotiations regarding wages, work conditions etc.). The received results of the research disclose that the majority of the respondents $(56.1 \%)$ positively valuate the possibility of constructive cooperation (see Figure 2).

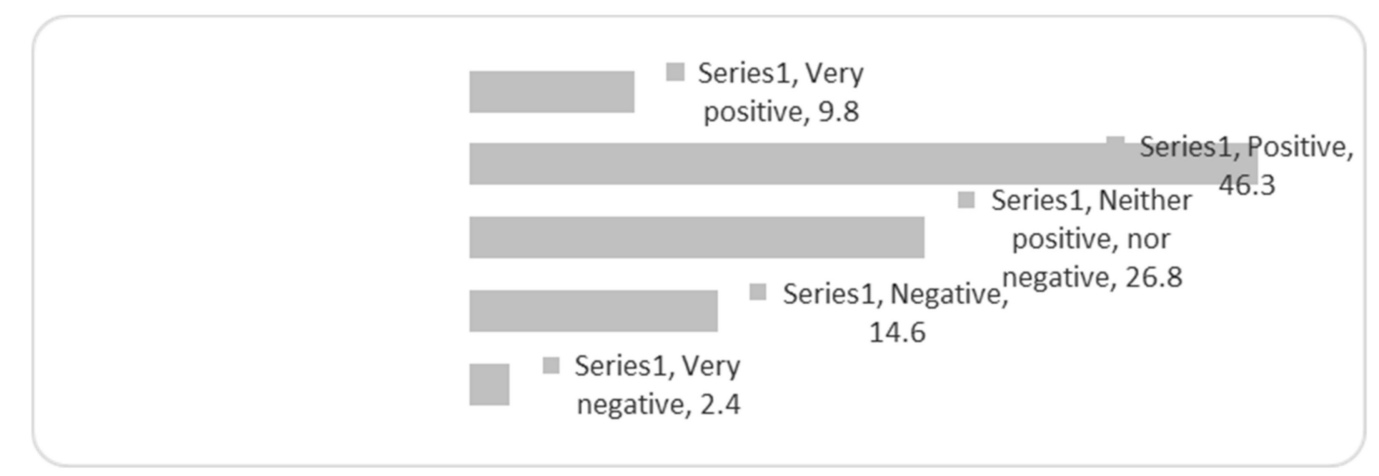

Figure 2. Points of View of the Respondents towards Cooperation with the Employers when Creating a Constructive Dialogue with the Employee Representatives (percentage).

It also should be highlighted that the respondents, who have represented the trade unions at the companies' level, evaluated more positively (positively 50.3\%), if compared to the representatives of national and branch trade unions. Furthermore, the answers of the respondents show that indirect participation is not underrated, if compared to other activity areas (see Figure 3). 


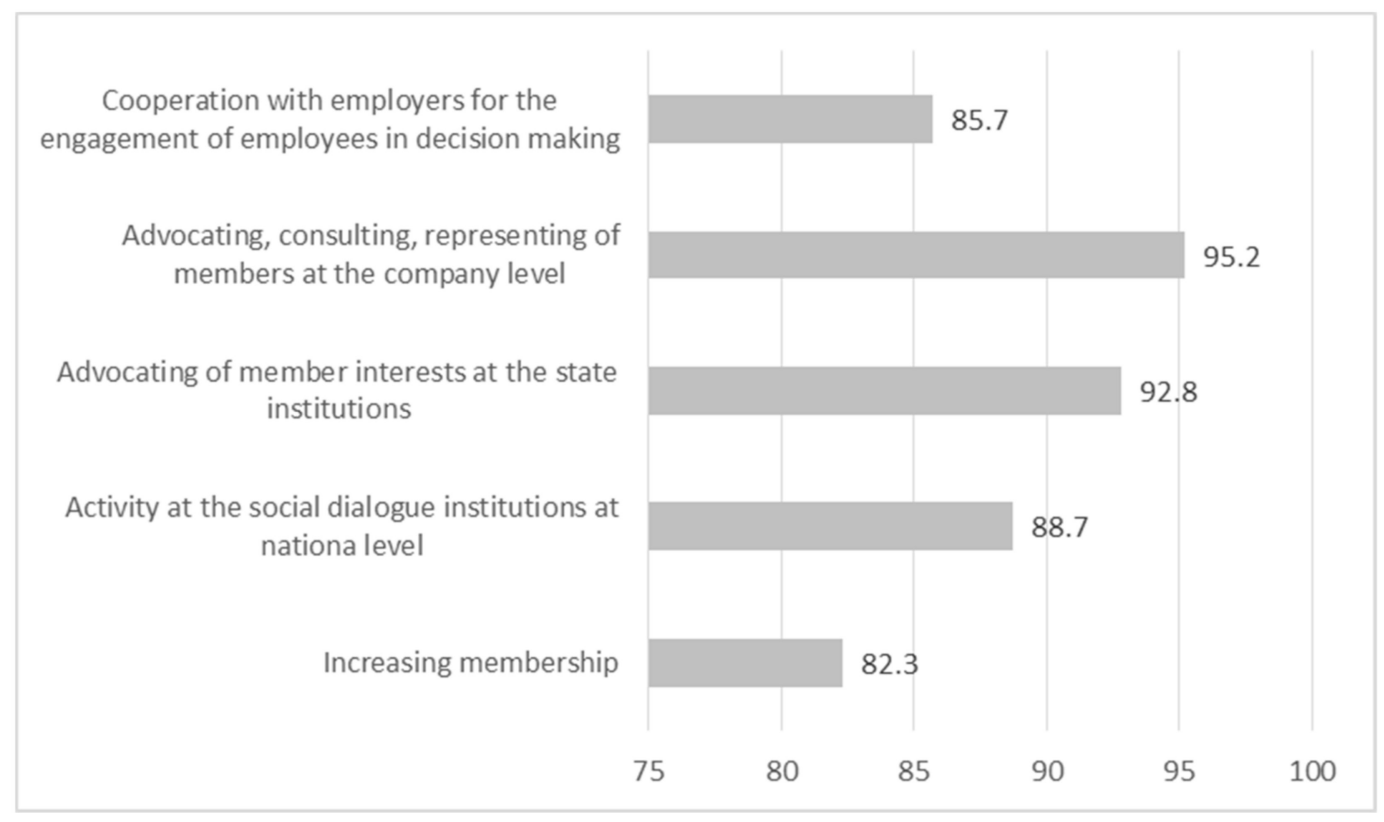

Figure 3. The Points of View of Respondents towards Priority Areas of the Activity of Employee Representatives (percentage).

\subsection{The Provisions Regarding the Inclusion of Employees into Teamwork and Collective Consulting}

During the interview, it was intended to determine the points of view of the informants towards the employee inclusion methods through teamwork (quality circles, issue solving teams and schemes of innovative proposals) or consultation (general meetings, in which the managers' report, and employee surveys) proposed by the employers. The majority of informants, who were the heads of national and branch trade unions, valued the employee participation forms proposed by the employers critically and very carefully. During the interview, they've mentioned that this is: "manipulation with participation" (interview with NAC3); "games that the employers play" (interview with NAC4); and "the kind of shady things, if of course the trade union is not involved" (interview with NAC7).

However, the chairpersons of trade unions, who encountered the phenomenon in practice, were a bit more positive. One authentic sharing of experience may be differentiated when reviewing the interview material:

"Within "Lietuvos Energija" this is indeed done, but not imitated. The culture in electrical companies is a bit higher than in industrial ones. Maybe, people that are more intellectual work here ... I do not know precisely why that is. Nevertheless, there are talks with the employees of the lowest tier. Well, this is done. [ ... ] I very much support this, if this is done honestly and there is feedback. The process must be two-fold; if this is done sincerely, then the result is splendid. The atmosphere of the collective itself is good. The employees know that an employee after talking with a higher-level manager may solve the problem. In "Lietuvos Energija" it became some sort of a manic thing for employees to propose how to solve certain problems. They offer many solutions; at first, this seemed like a game, but now it became a constant practice. The employee must propose a couple of novelties on how to enhance the process in order for to expedite it. They think things up and really do save money for the company. This is beneficial in a financial sense as well. Maybe, this can be applied not for all companies, but there are examples in the company "Lietuvos energijos skirstymo operatorius", where 2.5 thousand of employees' work. They generate benefit in Lithuania. They [the companies] even publicly announce how many ideas were implemented and accepted in order to turn them in to reality. [... ] Well, somehow there were tries [talking about the inclusion of questions associated with employment relations in to this kind of participation form], but it failed ... [laughs] We 
have a niche and are closer to employees. The managers, who are smarter and cannier, and want to know about the employees, cooperate with us. [interview with NAC5]

In this interview, the informant (in this case she does not only represent the national trade union, but the branch as well) mentions the schemes of supplying innovative proposals (applied individually and in teams), which are geared, first off all, towards the enhancement of technological and, in part, organizational processes. The informant, when evaluating the benefits for employees of this form of inclusion, differentiates a couple of arguments: proper employee incitement, creation of acceptable climate and consultations of managers with employees. On the other hand, she thinks that the means being discussed provides mutual benefit for employees and employers. An important observation is associated with financial benefit. During the interview, it was highlighted that the group of companies received a large financial benefit. In addition, the informant accentuated the aspect of transparency (the information regarding the means is made public and freely accessible) and development (this became a part of company's culture) of the means.

On the other hand, this interview discloses that the management of the company intended to use the scheme of the supply of innovative proposals in order to also include the discussion of employment relation issues. Nevertheless, the trade union of the aforementioned company "has stopped" the idea of the employers to "bypass" partially the active employee representatives. In accordance to the research material, it can be noticed, that participation mechanisms, which separate employment relation and other innovative solutions, are acceptable to trade unions.

Finally, a regard must be had, that these practices may be realized not in all manufacture or service supply sectors. They are more easily adapted in the area of average or high technologies and more difficult-in other areas of industry. In addition, in terms of organizational aspect, it is not possible to implement the collective participation everywhere (even in the case being discussed, it was coordinated with an individual employee participation).

The employers successfully implemented not all forms of employee team inclusion. During the qualitative research, the informant shared other experiences:

"These are issue solving teams shaped in our company. They meet every month and discuss the issues of manufacture and sales. There, they in a bit different angle discuss that, which we talk about on Monday meetings. [ ... ] Some proposals find their way with great difficulty. For example, regarding the electronic catalogue of the company for the suppliers. Many times, the managers went to the director ... and the head of the marketing proposed. [ . . ] No, there, the questions of employees are not the most important. Maybe, a couple of times they were discussed. Most often, the employees go to their managers, direct managers or general manager for negotiations. Discussions were during annual evaluation. [ ... ] Yes, teamwork regarding sustainability were organized. The corporation [the name is mentioned] implements the sustainable philosophy and laid down from above the requirements for daughter companies. We had discussions with the invited expert. I do not know, mostly about environmental safety, unused raw materials and ... While sitting in those meetings I was simply nervous. Complete waste of time. (interview with DT1)

A couple of observations are significant in this interview episode. Firstly, the informant, who is the representative of the work council, notices, that in the daughter companies of the international concern a couple of employee inclusion forms associated with the hearing out ${ }^{6}$ of the employee proposals (regarding the development and management of the organizing of activity) and the implementation of sustainable philosophy, culture and practical means. The facts submitted by the informant attest that the company applies the means envisaged in the policy of the corporation. They are possibly formal and redundant looking to the employees. On the other hand, indirect forms of employee inclusion

6 From the contextual information submitted during the interview, it could have been understood that the respondent was talking about small-medium sized wholesale company, in which more than 50 employees work. 
are applied in the company being discussed. By following the interview material, they are ineffective. The participant of the interview looked for reasons for why that is. In her opinion, the manager, who affirms the decisions, is partially conservative to novelties. In addition, she mentioned a "post-soviet" (the informant described this) management style and rigidity. It becomes clear from the interview, that in these participation processes the work councils do not have any influence, because their activity is formal and third-rate.

During the interview, the informants shared their experience on how the employees are informed and consulted with during meetings or when conducting surveys. Of course, exceptionally interesting was the point of view of trade unions towards these forms. One chairwoman of the trade union extensively told about the means applied in a large manufacture company (belonging to a concern):

"Somehow, this is done. We have quarterly meetings. There, everything is discussed on where everything is delivered, but the employees cannot ask questions. As if everyone lacks the time. We have boxes in our company where the proposals are incited to be submitted and they are evaluated. I do not know how they evaluate them [ ... ] I had to conduct a survey. We've conducted it a couple of years in a row. The employees and their issues are not solved. Moreover, they petitioned... There is a procedure that you may address the direct manager, if he/she does not solve the issue, then you can address the higher manager. However, the employees are deeply chagrined, because their issues are not solved directly. [ ... ] Simply we've discussed the problems via survey. We try to accumulate as many problems as we can and then we address the managers of the company. [... The manager of the factory has recently started to convene the meetings with the workers of sub-divisions, shifts and lines [there are talks that these meetings were decided to be convened due to negative audit results of the corporation regarding inappropriate climate. The audit results were submitted with comparative results of the indicators of all "daughter" companies. The audit was conducted after the employees were questioned]. In truth, I have yet to participate in such a meeting. I don't know how it will be. Of course, there will be people, who are afraid to express themselves. In addition, there are talkative people. Nevertheless, somehow, the results are not really seen. [... II would want a more active inclusion. Every time when you find-out about the meeting you have ask to be let it as a chairperson. Well ... this is how it is done. About a third of employees are trade union members. Such is the point of view when the minority of trade union (a third) participates. The rest do not need the trade union nor do they support it. As if, a mediator is not necessary. This is felt [ ... ] What I don't like the most is that there are unilateral decisions regarding inclusion. They do what is mandatory, but everything else it is difficult for them. They decide and propose. I would want some sort of a mutual link, a dialogue. (interview with IM1)

In this interview, a couple of forms of indirect employee informing and consultation are differentiated-current and special meetings in sub-divisions, acceptance of complaints and consulting (by individually accepting the employee and reviewing anonymous complaints), as well as employee surveys. During the interview it was noticed that the company in a form of meetings carries-out only the collective informing of employees (it is prohibited or employees do not have a possibility to give questions or express their opinion) and the real consultation is carried-out through the representatives of trade unions ${ }^{7}$.

Attention must be paid to the fact that the new form of indirect participation, i.e., the highest manager meetings with the employees, was initiated by the company's management only after the audit of the corporation, according to which the satisfaction of the employees of the manufacture

Other informants mentioned these often-encountered practices. In truth, they supplemented this by saying that such manipulation with consulting is especially often case in companies acting in smaller towns and in medium sized companies. A couple of reasons explained such practical phenomenon-conservative attitude of managers, the intention of direct or middle management to not disclose the issues of employees to the company's management and the well-established closed non-inclusion culture. 
company being discussed with the workplace and organizational climate was one of the lowest in Europe (interview with IM1). It seems that the management by reacting to these solutions initiated numerous meetings with the employees. In this case, it could be guessed that the management of the concern ("Mother Company") could have determined such initiative of the "daughter" company.

On the other hand, as the interview discloses, the trade union is not with good will included into the forms of consultation. It seems that obstacles are created for the participation of the chairperson of the trade union with an argument that the trade union represents the minority of employees. In addition, an argument is invoked that the trade union may rest on the forms of direct participation (it seems that the company adheres to them as to the obligations to sign the collective agreement).

The interview being discussed discloses how the forms of direct and indirect employee participation in the adoption of company's decisions are coordinated. Firstly, it is noticeable that the informant carefully, but positively valuates some means of indirect informing and consultation and intends to include them. Of course, the informant is happy that the company dutifully adheres to the obligations of the collective agreement, negotiates with the trade union etc., but at the same time she notices a "soft" try to push it out from the other forms of collective participation.

As it was mentioned, the theoreticians (especially, Unitarians or Pluralists) of employment relations think that these forms of employee informing and consulting may be successfully combined. The case of employment relations in the company being discussed discloses a different view. In this case, the company follows the contractual obligations and procedures defined by the laws; however, it does not want to include the trade union into other forms of consultations with employees.

The qualitative research has uncovered that the trade union representatives often under valuate the forms of indirect participation as secondary or are not familiarized with them, do not understand their functioning and possible benefit to the employees. Thus, with the help of employee representatives and experts survey it was intended to find-out how much the experts and employee representatives have familiarized and know about the forms of direct participation. The data received disclose that the respondents best known about the culture favorable to the employees and forms of creating management styles (see Table 3). They know less about forms of indirect participation through employee inclusion via teamwork etc. Nevertheless, the most unclear is the form of employee financial participation. Only $42 \%$ of respondents know about the financial participation of the employees.

Table 3. The Knowledge of Employees Related with Direct Participation and Other Means Proposed by the Employers.

\begin{tabular}{cccc}
\hline & Know about & $\begin{array}{c}\text { Don't know } \\
\text { about }\end{array}$ & $\begin{array}{c}\text { Neither know about, } \\
\text { nor don't know about }\end{array}$ \\
\hline $\begin{array}{c}\text { Financial participation of employees } \\
\text { Cooperation between the employees and } \\
\text { managers (collective reporting to } \\
\text { employees, consulting), democratic and } \\
\text { cooperative management style }\end{array}$ & 42.6 & 12.1 & 45.2 \\
$\begin{array}{c}\text { Teamwork, quality circles and other forms } \\
\text { Creation of cooperation climate, } \\
\text { organizational culture }\end{array}$ & 76.1 & 0.4 & 9.8 \\
\hline
\end{tabular}

In summarizing, it can be noted that the points of view of employee representatives towards the participation of employees are ambiguous and depend on the normative views, practical experiences and roles in trade unions. The qualitative research has uncovered that the employee representatives, while reviewing the initiatives of the employers, adhere to the pluralistic notions, i.e., relatively positively evaluate the employee inclusion forms applied by the employers, if they supplement the forms of direct participation (negotiations, collective agreement etc.). Only a couple of qualitative research participants expressed Unitarian views towards the phenomenon being reviewed. The informants by reflecting the employee participation forms noticed, that three conditions are important: mutual 
trust of employee and employer representatives, applied western management models ("daughter companies" of international corporations or some (there were talks about a lesser part) of socially responsible companies) and, exceptionally, western style managers (who tend to understand the benefit of cooperating with the trade unions and they realize this in practice in their companies).

The employee survey allowed evaluating the points of view of experts and employee representatives towards separate forms of employee participation (see Figure 4). The most suitable forms of employee inclusion for the respondents were those associated with inclusion processes, by which a qualitative consulting on employment issues (inclusion into the enhancement of company's quality processes through the so called quality circles seems less appealing) and decision control (i.e., appointing of employees to the boards) is ensured.

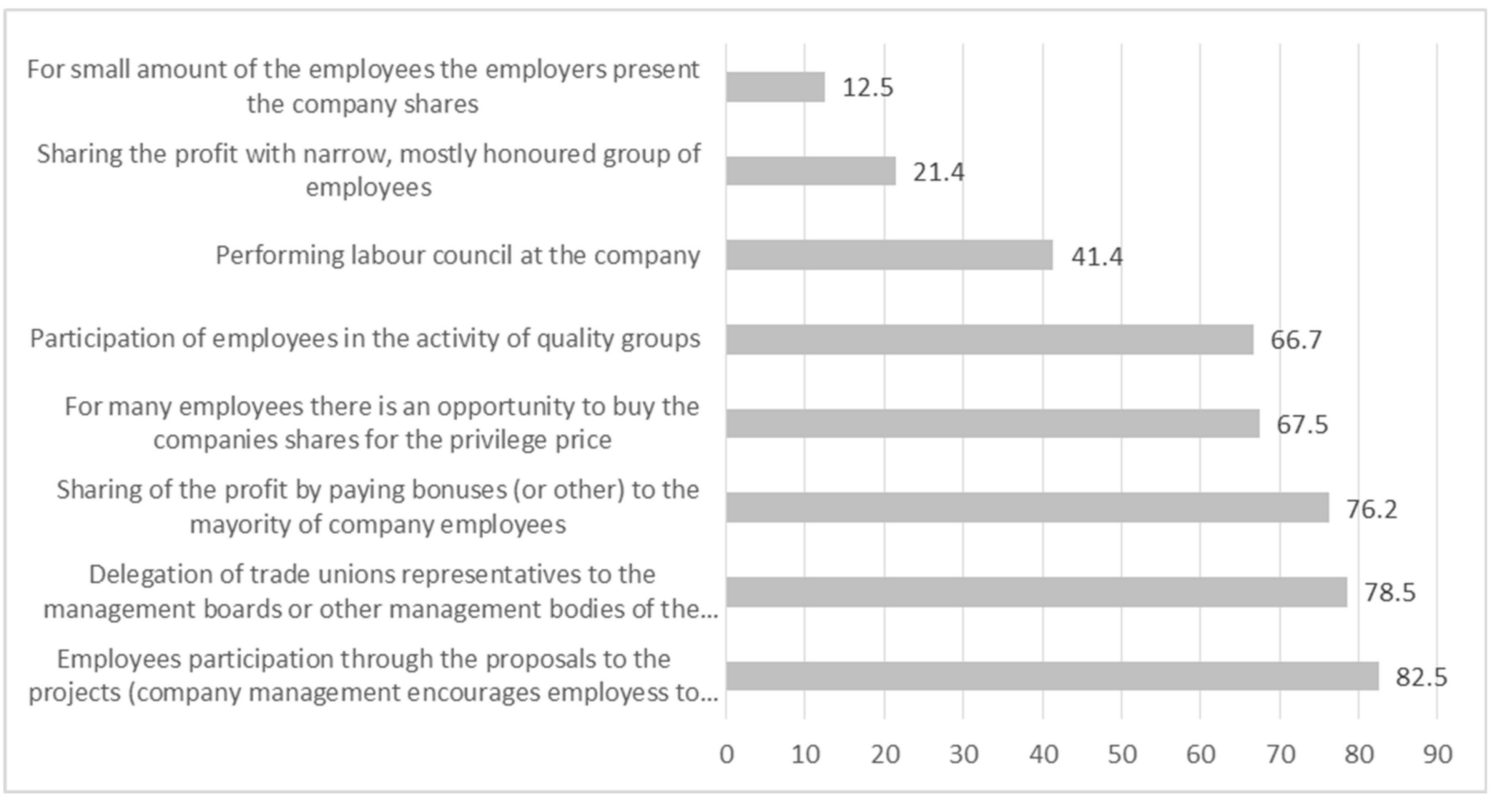

Figure 4. Points of View towards the Forms of Indirect Employee Inclusion Proposed by the Employers (positive evaluations*, percentage). * Only the positive answers were evaluated, when the respondents answered with a valuation "positively" or "very positively".

The experts found the two forms of financial employee inclusion acceptable, which envisage the collective inclusion of the majority of employees (see Figure 3). In this case, the respondents did not see an essential difference between the schemes of possible profit sharing or share acquisition. The so-called "narrow" schemes, when the profit or shares are attributed to a small number of employees, were evaluated very reservedly. By interpreting this normatively, it can be guessed, that the just allocation may be more important than the criterion of merits for the respondents.

The respondents evaluated the participation in the control of quality processes also positively. Whereas, the opinions on the performance of work council in the company were not evaluated positively. In this case, by asking a somewhat indecorous question (the law envisages the establishment and operation of such councils) it was intended to find-out how this form is evaluated (it is attributed more to the direct participation) in comparison to other forms. It is noticeable that $19.5 \%$ of respondents evaluated such employee representation as negative and only $4.9 \%$ as very positive.

Complex reasons determine the points of view of employee representatives towards separate forms of indirect participation. As the survey data show, the research participants least of all know about the financial participation of employees. The informants did not encounter this phenomenon in practice (especially, in the forms of share ownership) or did not associate it with the relevant topic of employee representation. In addition, a part of informants expressed critical or reserved notions in regard to the financial employee participation, by invoking a couple of arguments: (1) Currently, this is 
not relevant; and (2) this means is beneficial for employers. The employee trade union representatives, who participated in the research, positively evaluated the inclusion of employee representatives into the boards. The provisions regarding the employee inclusion into the teamwork and collective consulting were not ambiguous. The majority of informants, who were the heads of national and branch trade unions, evaluated the employee inclusion forms proposed by the employers critically as some sort of manipulation. The chairpersons of trade unions after encountering the phenomenon in practice were a bit more positive. They saw the benefit of these forms when they supplement the direct participation (trade union is active in the company; negotiations are held and the collective agreement has been signed).

\section{Conclusions}

Based on the finding of the research, the employee participation is understood as a multiple phenomenon. The scientists associate this topic with different disciplines and research directions. Ideological and value notions, as well as interests determine the points of view of employees and employers towards this phenomenon. Often, they are cardinally contradictory, but sometimes they look for constructive points of contact and agreements. The employee participation in the adoption of company's decisions may be direct or indirect. Direct employee participation is understood as "participation of representatives" (the elected or appointed representatives of trade unions or employee council in the boards etc.). Sometimes, this form is called a social dialogue at the company level (Mailand and Due 2004). Indirect participation encompasses individual and collective forms of employee participation in the adoption of company's decisions. The employers initiate and induce the inclusion of employees in the company, by consulting or delegating responsibilities in the adoption of governing decisions. Many researchers notice that the forms of indirect and direct employee participation often overlap and supplement each other.

The qualitative research data and survey disclosed that the points of view of employee representatives towards indirect participation of employees are ambiguous and depend upon the normative views, practical experiences and roles in the trade unions. The qualitative research disclosed that the employee representatives while reviewing the initiatives of the employers adhere to the pluralistic provisions, i.e., relatively positively valuate the forms of employee inclusion applied by the employers, if they supplement the forms of direct participation (negotiations, collective agreement etc.). Only a couple of qualitative research participants expressed unitarian views towards the phenomenon being reviewed. The informants while reflecting the forms of employee participation have noticed, that there are three important conditions: mutual trust of employee and employer representatives, applied Western management models ("daughter companies" of international corporations or some (there were talks about lesser part of them) socially responsible companies) and exceptionally "democratic" style managers (who tend to understand the benefit of cooperating with the trade unions and realize this in practice in their companies).

National factors may determine the views towards direct participation of employees in the adoption of company's decisions: historical development, which have formed independent institutional norms, type of capitalism, model of employment relations and other. Often, these factors completely influence the employee participation. However, even in Austria and Germany where employee participation has a significant role, the representation mainly observed in the large companies (European Commission 2018). The synthesis of collected and scientific research data allows stating, that an exceptional feature of the model of employment relations is weak representation of employees. It means, that individual employment relations prevail in Lithuania. The second exceptionality is associated with the expression of informal industrial relations, which influences not only the employee representation, but the direct (formal) participation on the company level as well. Weak evaluation of industrial relations creates suppositions for it. The conducted researches show that the regulation, which was strengthened by the 2016 reform, may only change the situation in part. On the other hand, due to the lack of researches and having regard to the fact that relatively small time has passed 
since the implementation of the reform, unambiguously and without reservations this cannot be stated. The qualitative research has affirmed the importance of the aforementioned phenomenon for the employee representatives. The informants skeptically evaluated the influence of recently affirmed Labor Code on the institutes of industrial relations-operation of work councils and signing of collective agreements.

Complex reasons determine the points of view of employee representatives towards the forms of indirect participation. As the interview and survey data show, the research participants least know about and understand the financial participation of employees. The informants have not encountered this phenomenon in practice (especially, with the forms of share ownership) or did not associate them with the relevant topic of employee representation. Moreover, a couple of informants expressed critical or reserved attitudes towards financial participation of the employees by resting on a couple of arguments: (1) Currently this is not relevant; and (2) this means is beneficial for employers. The representatives of employee trade unions, who participated in the research, positively evaluated the inclusion of employee representatives into the boards. The analysis of interview material uncovered, that the representatives of national trade unions have actively tried to include the appointment of employee representatives into the boards when preparing the new Labor Code.

To sum up, the future research in the field may be oriented to find out the answers to the questions: (i) What are the consequences of the use of employees' representatives in the adoption decision for the companies; (ii) Is the use of employees' representatives in the adoption of company's decision offer opportunities or risks; (iii) how does corporate culture affect the scope of use the employees representation in the adoption decision of company (iv) how does the use of artificial intelligence affect the use of employees representation in adoption decision of company.

Author Contributions: All authors contributed equally to this paper.

Acknowledgments: In this section you can acknowledge any support given which is not covered by the author contribution or funding sections. This may include administrative and technical support, or donations in kind (e.g., materials used for experiments).

Conflicts of Interest: The authors declare no conflict of interest.

\section{References and Note}

Barry, Michael, and Adrian Wilkinson. 2016. Pro-social or pro-management? A critique of the conception of employee voice as a pro-social behaviour within organizational behaviour. British Journal of Industrial Relations 54: 261-84. [CrossRef]

Blažienė, Inga, and Boguslavas Gruževskis. 2017. Lithuanian Trade Unions: From Survival Skills to Innovative Solutions. In Innovative Union Practices in Central-Eastern Europe. Edited by Magdalena Bernaciak and Marta Kahancová. Brussels: European Trade Union Institute.

Blyton, Paul, and Peter J. Turnbull. 1998. The Dynamics of Employee Relations. New York: Palgrave Macmillan.

Brewster, Chris, Richard Croucher, Geoff Wood, and Michael Brookes. 2007. Collective and individual voice: convergence in Europe? The International Journal of Human Resource Management 18: 1246-62. [CrossRef]

Civinskas, Remigijus, and Jaroslav Dvorak. 2017. New social cooperation model in service oriented economy: the case of employee financial participation in the Baltic states. Engineering Management in Production and Services 9: 37-50. [CrossRef]

Crouch, Colin. 2017. Membership density and trade union power. Transfer: European Review of Labour and Research 23: 47-61. [CrossRef]

Della Torre, Edoardo. 2018. Collective voice mechanisms, HRM practices and organizational performance in Italian manufacturing firms. European Management Journal 37: 1-13. [CrossRef]

Detert, James R., and Linda Klebe Treviño. 2010. Speaking up to higher-ups: How supervisors and skip-level leaders influence employee voice. Organization Science 21: 249-70. [CrossRef]

Dvorak, Jaroslav, Raita Karnite, and Arvydas Guogis. 2018. The Characteristic Features of Social Dialogue in the Baltics. Socialiné Teorija, Empirija, Politika ir Praktika 16: 26-36. [CrossRef] 
Eurofound. 2015. Third European Company Survey: Direct and Indirect Employee Participation. Luxembourg: Publications Office of the European Union.

Eurofound. 2016. Mapping Key Dimensions of Industrial Relations. Luxembourg: Publications Office of the European Union.

Eurofound. 2018. Measuring Varieties of Industrial Relations in Europe: A Quantitative Analysis. Luxembourg: Publications Office of the European Union.

European Commission. 2002. Report of the High-Level Group on Industrial Relations and Change in the European Union. Luxembourg: Publications Office of the European Union.

European Commission. 2017. Commission Recommendation Establishing the European Pillar of Social Rights. Brussels: European Commission, April 26.

European Commission. 2018. COMMISSION STAFF WORKING DOCUMENT IMPACT ASSESSMENT Accompanying the document Proposal for a Directive of the European Parliament and of the Council amending Directive (EU) 2017/1132 as regards the use of digital tools and processes in company law and Proposal for a Directive of the European Parliament and of the Council amending Directive (EU) 2017/1132 as regards cross-border conversions, mergers and divisions. Brussels: European Commission, p. 63.

European Parliament and Council. 2002. Directive 2002/14/EC 11 March 2002 establishing a general framework for informing and consulting employees in the European Community. Official Journal L080: 29-33.

Gollan, Paul J. 2010. Employer Strategies towards Non-Union Collective Voice. In The Oxford Handbook of Participation in Organizations. Edited by Adrian Wilkinson, Paul J. Gollan, Mick Marchington and David Lewin. Oxford: Oxford University Press.

Gollan, Paul J., and Ying Xu. 2015. Re-engagement with the employee participation debate: Beyond the case of contested and captured terrain. Work, Employment and Society 29: NP1-NP13. [CrossRef]

Heery, Edmund James. 2015. Frames of reference and worker participation. In Finding A Voice at Work?: New Perspectives on Employment Relations. Edited by Stewart Johnstone and Peter Ackers. Oxford: Oxford University Press.

Hyman, R. 2018. What future for industrial relations in Europe? Employee Relations 40: 569-79. [CrossRef]

Johnstone, Stewart, and Adrian Wilkinson. 2016. Developing Positive Employment Relations: International Experiences of Labour-Management Partnership. In Developing Positive Employment Relations. London: Palgrave Macmillan.

Kaufman, Bruce E. 2015. Theorizing determinants of employee voice: An integrative model across disciplines and levels of analysis. Human Resource Management Journal 25: 19-40.

Kim, Jaewon, John Paul MacDuffie, and Frits K. Pil. 2010. Employee voice and organizational performance: Team versus representative influence. Human Relations 63: 371-94. [CrossRef]

Kozłowski, Maciej. 2014. The Relationship between Workers' Financial Participation in Companies and Economic Results. Comparative Economic Research 17: 167-91. [CrossRef]

Laurènas, Vaidutis. 2017. Spartėjančios visuomenès politinis režimas. Klaipèda: Klaipèdos universiteto leidykla.

Lulle, Aija. 2013. Estonia, Latvia, Lithuania-Labour relations and social dialogue. In Regional Project on Labour Relations and Social Dialogue. Stockholm: Confederation of Swedish Enterprise.

Machado, Ricardo B. 2016. The determinants of employee ownership plan implementation in EU countries-the quest for economic democracy: A first look at the evidence. Organizacija 49: 94-107. [CrossRef]

Mailand, Mikkel, and Jesper Due. 2004. Social dialogue in Central and Eastern Europe: present state and future development. European Journal of Industrial Relations 10: 179-97. [CrossRef]

Marchington, Mick, and Adrian Wilkinson. 2005. Direct participation and involvement. In Managing Human resources: Personnel Management in Transition. Maiden, Oxford and Carlton: Wiley.

Marchington, Mick, and Jane Suter. 2013. Where informality really matters: Patterns of employee involvement and participation (EIP) in a non-union firm. Industrial Relations: A Journal of Economy and Society 52: 306-7. [CrossRef]

Marginson, Paul. 2017. European Industrial Relations: An increasingly fractured landscape? Warwick Papers in Industrial Relations 106: 1-2.

Markey, Raymond, and Herman Knudsen. 2014. Employee participation and quality of work environment: Denmark and New Zealand. International Journal of Comparative Labour Law and Industrial Relations 30: 105-26.

Markey, Raymond, and Keith Townsend. 2013. Contemporary trends in employee involvement and participation. Journal of Industrial Relations 55: 475-87. [CrossRef] 
Mowbray, Paula K., Adrian Wilkinson, and Herman HM Tse. 2015. An integrative review of employee voice: Identifying a common conceptualization and research agenda. International Journal of Management Reviews 17: 382-400. [CrossRef]

OECD. 2018. Trade union density. Organization for economic co-operation and development. Available online: https://stats.oecd.org/Index.aspx?DataSetCode=TUD (accessed on 4 October 2019).

Pateman, Carole. 1970. Participation and Democratic Theory. Cambridge: Cambridge University Press.

Pučetaitè, R., V Jurènienè., and A. Novelskaitè. 2014. Lithuania: CRS on a wish list. In Corporate Social Responsibility and Trade Unions: Perspectives across Europe. Edited by Lutz Preuss, Michael Gold and Chris Rees. London and New York: Routledge.

Shpak, Nestor Omelyanovych, Natalia Stepanivna Stanasiuk, Oleh Volodymyrovych Hlushko, and Włodzimierz Sroka. 2018. Assessment of the social and labor components of industrial potential in the context of corporate social responsibility. Polish Journal of Management Studies 17: 209-19. [CrossRef]

Sippola, Markku. 2017. Ideological underpinnings of the development of social dialogue and industrial relations in the Baltic States. Available online: http://www.lpsk.lt/lpsk-web/wp-content/uploads/2017/02/Baltic-IRdevelopment-Sippola-2017-02-23.pdf (accessed on 4 October 2019).

Šimanskienè, Ligita, and Erika Župerkienè. 2013. Darnus vadovavimas. Klaipėda: Klaipèdos universiteto leidykla. Wilkinson, Adrian, and Tony Dundon. 2010. Direct Employee Participation. In The Oxford Handbook of Participation in Organizations. Edited by Adrian Wilkinson, Paul J. Gollan, Mick Marchington and David Lewin. Oxford: Oxford University Press.

Wilkinson, Adrian, Tony Dundon, and Mick Marchington. 2013. Employee Involvement and Voice. In Managing Human Resources-Human Resource Management in Transition. Edited by Stephen Bach and Martin Edwards. West Sussex: Wiley.

(C) 2019 by the authors. Licensee MDPI, Basel, Switzerland. This article is an open access article distributed under the terms and conditions of the Creative Commons Attribution (CC BY) license (http://creativecommons.org/licenses/by/4.0/). 